\title{
Meta-analysis of associations between telomere length and colorectal cancer survival from observational studies
}

\author{
Wei Wang ${ }^{1, *}$, Lei Zheng ${ }^{2, *}$, Ning Zhou ${ }^{1, *}$, Na $\mathrm{Li}^{1}$, Gilisihan Bulibu ${ }^{1}$, Chunlei $\mathrm{Xu}^{1}$, \\ Yi Zhang ${ }^{3}$ and Yong Tang ${ }^{1}$ \\ ${ }^{1}$ Department of Digestive Internal Medicine, The Affiliated Tumor Hospital of Xinjiang Medical University, Urumqi, Xin Jiang \\ Province, China \\ ${ }^{2}$ Department of Endocrinology, The First Affiliated Hospital of Chinese PLA General Hospital, Beijing, China \\ ${ }^{3}$ Department of Pharmacy, The First People's Hospital of Jiashan, Jiashan County, Jiaxing City, Zhejiang Province, China \\ *Authors contributed equally to this work
}

Correspondence to: Yong Tang, email: yongtang_vip@126.com

Yi Zhang, email: flowerier123@126.com

Keywords: colorectal cancer, telomere length, meta-analysis, survival

Received: June 02, 2017 Accepted: July 25, $2017 \quad$ Published: August 07, 2017

Copyright: Wang et al. This is an open-access article distributed under the terms of the Creative Commons Attribution License 3.0 (CC BY

3.0), which permits unrestricted use, distribution, and reproduction in any medium, provided the original author and source are credited.

\section{ABSTRACT}

Background: Telomere length (TL) has been reported to be associated with the risk and survival of several cancers. But it is unclear for the prognostic role of TL in colorectal cancer (CRC).

Materials and Methods: Relevant citations were searched and identified using several major online databases through April 2017 which investigated associations between TL and CRC prognosis. We combined summary estimates using hazard ratios (HRs) with $95 \%$ confidence interval (CI), which were pooled using a random-effects model. Overall survival (OS) was set as the primary outcome of interest.

Results: There are 8 cohort studies encompassing 1622 patients included in the meta-analysis. Pooled estimate indicated that long TL was not significantly associated with patient OS (HR 1.26, 95\% CI, 0.76 to 2.08). When we conducted subgroup analyses based on baseline charcteristics, we found that long TL (versus short TL) was significantly associated with poor OS in studies conducted in Europe $(n=4$, HR $2.73,95 \% \mathrm{CI}, 1.65$ to $\left.4.52, \mathrm{I}^{2}=0\right)$, using Southern blot to measure TL $(n=3, \mathrm{HR}$ $2.93,95 \% \mathrm{CI}, 1.69$ to $\left.5.10, \mathrm{I}^{2}=0\right)$ and patients' age more than 60 years $(n=3, \mathrm{HR}$ $2.65,95 \% \mathrm{CI}, 1.22$ to $5.76, \mathrm{I}^{2}=0$ ). We found no significant associations between TL and patient disease-free, recurrence-free or progression-free survival (HR 1.19, 95\% CI, 0.45 to 3.15 ).

Conclusions: Current evidence did not provide solid indication that long TL is significantly associated with improved or poor survival for patients with CRC. Further large sample size prospective cohort studies are warranted to determine the true relationship for specific patients.

\section{INTRODUCTION}

As a critical structure with numerous DNA sequences of TTAGGG tandem repeats located at the end of linear chromosomes in eukaryote cells, telomere has reported to plays an important role in the protection of genomic instability and DNA degradation $[1,2]$. The persistent cell proliferation makes telomere shorten year by year, and meanwhile telomerase activity decreases gradually. The chromosome instability resulting from abnormal alteration of telomere length (TL) may lead to carcer occurance [3].

The associations between TL and cancer risk, mortality and progression have been reported in numerous studies with controversial results [4-14]. Svenson et al. found that TL was shorter in tumor tissues than the adjacent non-tumorous tissues [15]. Moreover, studies 
in a number of malignancies have showed that abnormal alternation of TL in peripheral blood leukocytes is significantly correlated with the mortality and progression of cancer patients, such as breast cancer, prostate cancer, gastric cancer and non-small cell lung cancer [16-19]. the prognostica value of TL for colorectal cancer (CRC) has not been fully determined.

In a meta-analysis conducted by Zhang et al. [20], they found that short telomeres were associated with increased CRC mortality, which was also reported by Jia et al [21]. However, due to the small sample size and great heterogeneity among studies in those two studies, we updated the systematic review and meta-analysis to reevaluate the prognostic significance of TL in CRC.

\section{RESULTS}

\section{Description of the search and selection of studies}

There were a total of 1119 citations identified for eligibility through database search. After exclusion of duplicate publications, screening of the titles or abstracts, there remained 43 citations for full text review. When excluding the studies unsatisfied for the inclusion criteria, we finally enrolled a total of 8 cohort studies encompassing 1622 patients with a median sample size of 131 (range 57 to 571) for this meta-analysis [22-29]. Data on OS and disease-free survival (DFS)/recurrencefree survival (RFS)/progression-free survival (PFS) were available from 7 and 5 studies, respectively (Figure 1).

\section{Study characteristics}

The basic elements of all the included studies are presented in Table 1. They were all published in English peer-reviewed journals between 2004 and 2016. Five of 8 of the included studies were conducted in Europe, the other three were in USA, Australia and China, respectively. The sample origins were from peripheral leukocytes in two studies [23, 28] while others were from tumor tissues [22, 24-27, 29]. Eight studies investigated I-IV stage CRC patients and only one of them involved stage IV patients [29]. Five studies used qPCR to measure TL while three used Southern blot. The Newcastle-Ottawa scale (NOS) score of methodological quality assessment ranged from 6 to 8 with 5 studies gaining a score of 7 or above (Table 1).

\section{Telomere length and colorectal cancer survival}

\section{Overall survival}

Pooled estimate indicated that long TL was not significantly associated with patient OS (hazard ratio [HR] $1.26,95 \%$ confidence interval [CI], 0.76 to 2.08) (Figure 2) and significant inter-study heterogeneity $\left(\mathrm{I}^{2}=82.7 \%\right.$, $P<0.001)$ was noted. When we conducted subgroup analyses based on baseline charcteristics (Table 2), we found that long TL (versus short TL) was significantly associated with poor OS in studies conducted in Europe ( $n=4$, HR 2.73, 95\% CI, 1.65 to 4.52$)$, using Southern blot to measure TL $(n=3$, HR 2.93, 95\% CI, 1.69 to

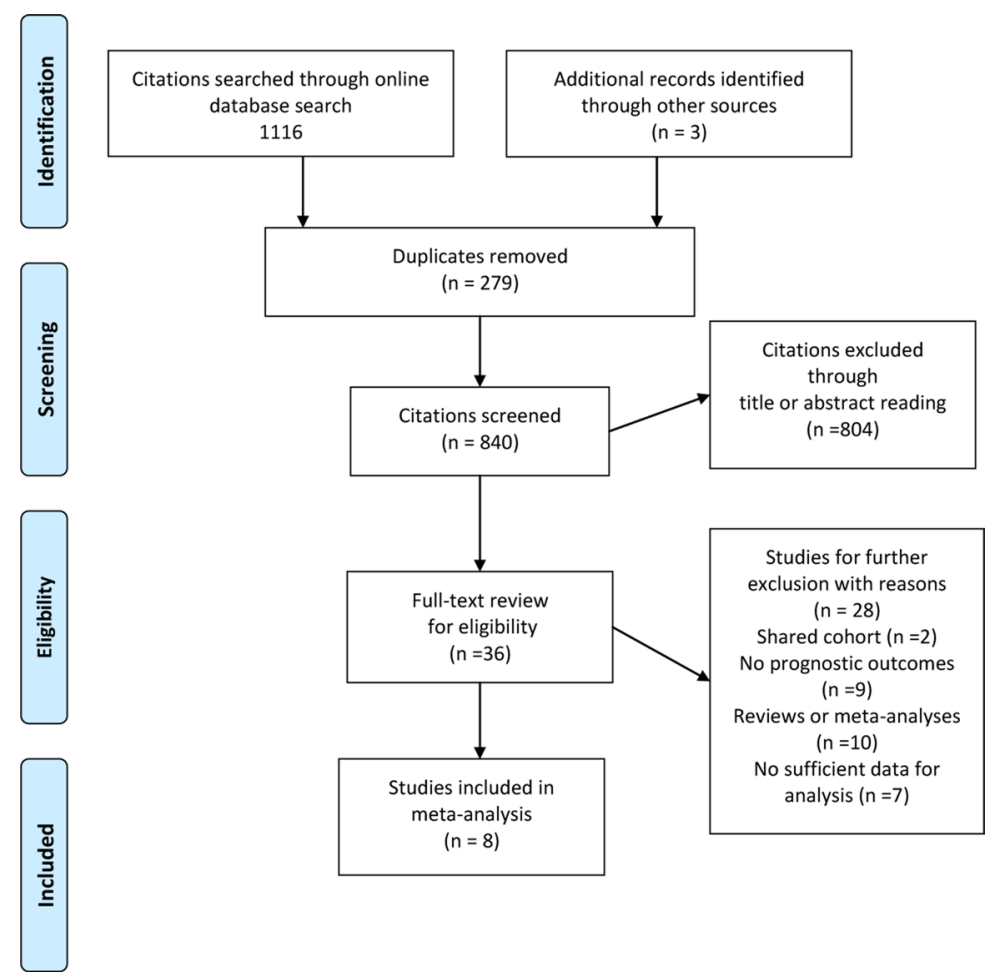

Figure 1: Flow diagram of study selection process investigating effect of telomere length on colorectal cancer prognosis. 
Table 1: Study features of included studies investigating the survival outcomes of telomere length for colorectal cancer patients

\begin{tabular}{|c|c|c|c|c|c|c|c|c|c|c|c|c|}
\hline Author & Country & Sample origin & $\begin{array}{l}\text { Sample } \\
\text { size }\end{array}$ & $\begin{array}{l}\text { Mean/ } \\
\text { median } \\
\text { age(ys) }\end{array}$ & $\begin{array}{l}\text { Tumor } \\
\text { stage }\end{array}$ & Treatment regimen & $\begin{array}{l}\text { Assay/ } \\
\text { detection } \\
\text { method }\end{array}$ & Cut-off & $\begin{array}{c}\text { Follow up } \\
\text { period (months) }\end{array}$ & $\begin{array}{l}\text { Outcome } \\
\text { reported }\end{array}$ & Adjustment factors & Quality \\
\hline $\begin{array}{l}\text { Svenson, } \\
2016\end{array}$ & Sweden & $\begin{array}{l}\text { Peripheral } \\
\text { leukocytes }\end{array}$ & 130 & Mean 70 & I-IV & Surgery & $\mathrm{qPCR}$ & NR & $\begin{array}{l}\text { Median } 202 \\
\text { months. }\end{array}$ & OS & $\begin{array}{l}\text { Age, lymphocyte } \\
\text { tumor infiltration, } \\
\text { and metastatic status }\end{array}$ & 6 \\
\hline $\begin{array}{l}\text { Suraweera, } \\
2016\end{array}$ & Australia & Tumor tissue & 419 & $\begin{array}{l}\text { Median } 70 \\
\text { (30 to } 92 \text { ) }\end{array}$ & I-IV & Adjuvant treatment & qPCR & NR & $\begin{array}{l}\text { Median } \\
\text { OS 5.2; } \\
\text { PFS } 41.6\end{array}$ & OS, DFS & $\begin{array}{l}\text { Gender, age, } \\
\text { tumor site, stage, } \\
\text { differentiation }\end{array}$ & 7 \\
\hline $\begin{array}{l}\text { Ferandez- } \\
\text { Marcelo, } \\
2016\end{array}$ & Spain & Tumor tissue & 132 & Median 71 & $\begin{array}{l}\text { Dukes } \\
\text { Stage } \\
\text { A-D }\end{array}$ & surgery & $\mathrm{qPCR}$ & $6.35 \mathrm{~kb}$ & $\begin{array}{l}\text { Median } \\
60(1-110) .\end{array}$ & DFS & $\begin{array}{l}\text { Gender, age, tumor } \\
\text { location, Dukes stage }\end{array}$ & 7 \\
\hline $\begin{array}{l}\text { Augustine, } \\
2015\end{array}$ & USA & Tumor tissue & 75 & $\begin{array}{l}\text { Median } 60 \\
(34-93)\end{array}$ & IV & $\begin{array}{l}\text { EGFR inhibitors } \\
\text { treatment }\end{array}$ & qPCR & $\begin{array}{c}\text { Median } \\
\text { length }\end{array}$ & NR & OS, PFS & $\begin{array}{l}\text { Age, gender, and } \\
\text { race. }\end{array}$ & 6 \\
\hline Chen, 2014 & China & $\begin{array}{l}\text { Peripheral } \\
\text { leukocytes }\end{array}$ & 571 & 60 & I-IV & $\begin{array}{l}\text { Surgery+adjuvant } \\
\text { chemotherapy }\end{array}$ & qPCR & 0.704 & $\begin{array}{c}\text { Median } \\
28(6-60)\end{array}$ & OS, RFS & $\begin{array}{l}\text { Age, sex, tumor } \\
\text { location }\end{array}$ & 8 \\
\hline Valls, 2011 & Spain & Tumor tissue & 147 & NR & I-IV & Adjuvant therapy & $\begin{array}{l}\text { Southern } \\
\text { blot }\end{array}$ & 1 & Mean 45 & os & $\begin{array}{l}\text { Age,gender, N } \\
\text { classification,TNM } \\
\text { classification, tumor } \\
\text { site, tumor histology, } \\
\text { adjuvant therapy }\end{array}$ & 7 \\
\hline $\begin{array}{l}\text { Garcia- } \\
\text { Aranda, } \\
2006\end{array}$ & Spain & Tumor tissue & 91 & $\begin{array}{l}\text { Average } \\
68.60\end{array}$ & I-IV & Adjuvant therapy & $\begin{array}{l}\text { Southern } \\
\text { blot }\end{array}$ & $\begin{array}{l}\text { Mean } \\
\text { length }\end{array}$ & $\begin{array}{c}\text { Median } \\
43.86(1-77)\end{array}$ & DFS & $\begin{array}{c}\text { Gender, age, } \\
\text { Dukes stage, tumor } \\
\text { location, and } \\
\text { differentiation grade } \\
\text { of tumors }\end{array}$ & 6 \\
\hline $\begin{array}{l}\text { Gertler, } \\
2004\end{array}$ & Germany & Tumor tissue & 57 & Mean 64.6 & I-IV & $\begin{array}{c}\text { Adjuvant } \\
\text { radiochemotherapy }\end{array}$ & $\begin{array}{l}\text { Southern } \\
\text { blot }\end{array}$ & 0.9 & $\begin{array}{c}\text { Median } \\
75.5(52 \text { to } 87)\end{array}$ & OS & $\begin{array}{c}\text { Tumor site, } \\
\text { histologic grade, } \\
\text { sex, and age, depth } \\
\text { of tumor invasion } \\
(\mathrm{pT}), \text { lymph node } \\
\text { status, and lymphatic } \\
\text { invasion and hTERT } \\
\text { expression }\end{array}$ & 8 \\
\hline
\end{tabular}

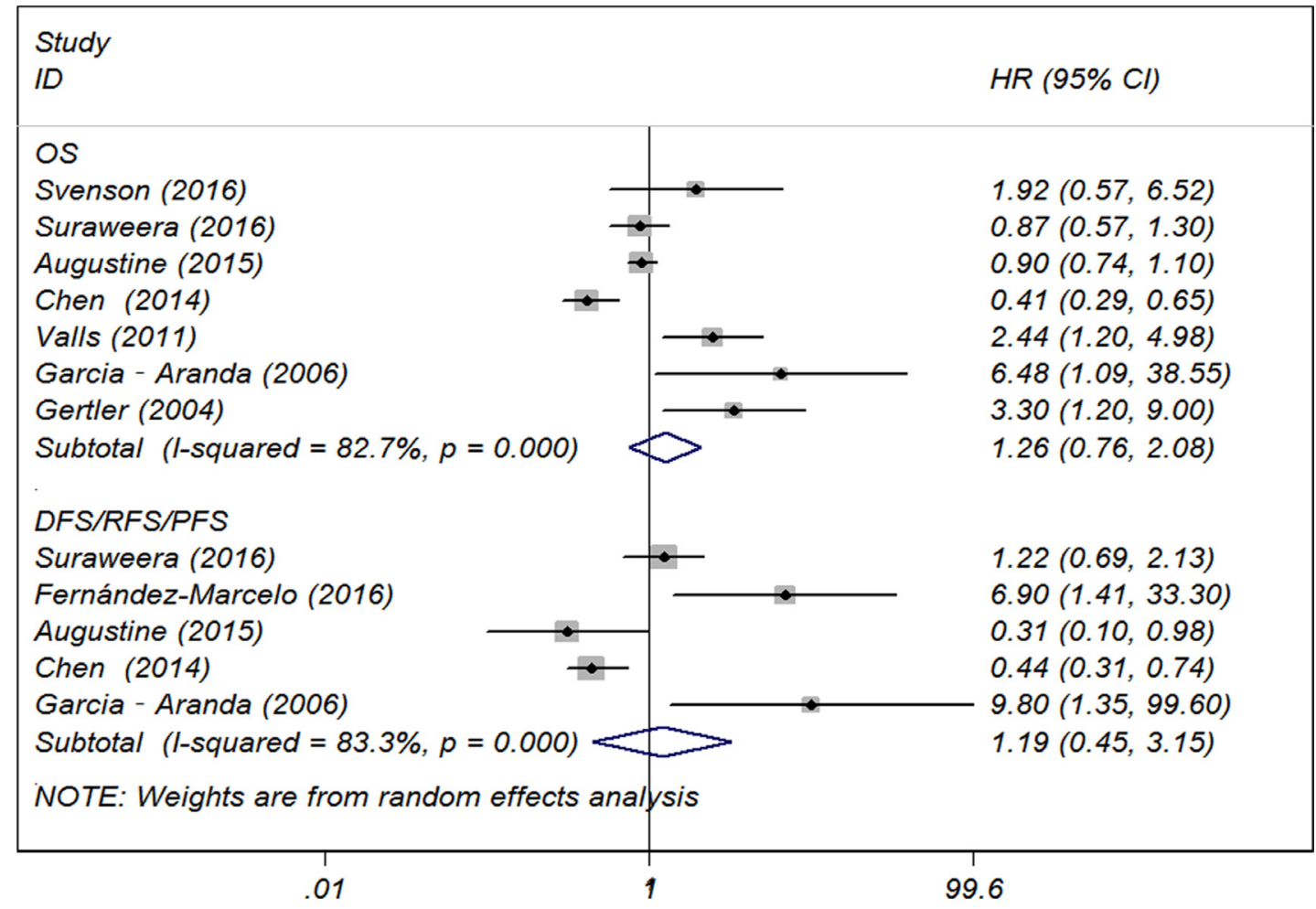

Figure 2: Forest plot of included studies examining the association between telomere length and overall survival. 
Table 2: Subgroup analyses based on some baseline features of included studies for overall survival

\begin{tabular}{|c|c|c|c|c|c|}
\hline & Hazard ratio & $\begin{array}{l}\text { 95\% Confidence } \\
\text { interval }\end{array}$ & $\begin{array}{c}\text { Degree of } \\
\text { heterogeneity } \\
\left(\mathrm{I}^{2} \text { statistics; \%) }\right.\end{array}$ & $P$-value & $\begin{array}{l}\text { No. of included } \\
\text { Studies }\end{array}$ \\
\hline \multicolumn{6}{|l|}{ Sample origin } \\
\hline Peripheral blood & 0.74 & 0.18 to 3.55 & 82.0 & 0.76 & 2 \\
\hline Tumor tissue & 1.53 & 0.89 to 2.61 & 76.7 & 0.12 & 5 \\
\hline \multicolumn{6}{|l|}{ Study region } \\
\hline Europe & 2.73 & 1.65 to 4.52 & 0 & $<0.001$ & 4 \\
\hline Others & 0.70 & 0.43 to 1.12 & 82.7 & $<0.001$ & 3 \\
\hline \multicolumn{6}{|l|}{ Mean/median age (ys) } \\
\hline$<65$ & 0.93 & 0.42 to 2.03 & 89.7 & 0.85 & 3 \\
\hline$\geq 65$ & 1.69 & 0.59 to 4.85 & 65.1 & 0.33 & 3 \\
\hline \multicolumn{6}{|l|}{ Sample size } \\
\hline$<100$ & 2.19 & 0.64 to 7.48 & 81.1 & 0.21 & 3 \\
\hline$\geq 100$ & 1.04 & 0.47 to 2.30 & 86.3 & 0.92 & 4 \\
\hline \multicolumn{6}{|l|}{ TL detection method } \\
\hline qPCR & 0.77 & 0.49 to 1.12 & 78.6 & 0.26 & 4 \\
\hline Southern blot & 2.93 & 1.69 to 5.10 & 0 & $<0.001$ & 3 \\
\hline \multicolumn{6}{|c|}{ Follow-up period (ms) } \\
\hline$<60$ & 1.21 & 0.50 to 2.94 & 88.1 & 0.68 & 4 \\
\hline$\geq 60$ & 2.65 & 1.22 to 5.76 & 0 & 0.01 & 3 \\
\hline
\end{tabular}

Abbreviations: ms, months; TL, telomere length; ys, years.

5.10) and patients' age more than $60(n=3$, HR 2.65, $95 \%$ CI, 1.22 to 5.76 ). The inter-study heterogeneity of all the three above subgroups decreased significantly (all $I^{2}=0$ ). However, we did not find significant prognostic associations between TL and CRC OS stratified by sample origin (peripheral blood or tumor tissue), patient mean/ median age $(<65$ years or $\geq 65$ years) or sample size $(<100$ or $\geq 100)$ (Table 2$)$.

\section{Disease/recurrence/progression-free survival}

We found no significant associations between TL and patient DFS/RFS/PFS (HR 1.19, 95\% CI, 0.45 to 3.15) (Figure 2) with significant inter-study heterogeneity $\left(I^{2}=83.3 \%, P<0.001\right)$. As limited studies for this outcome subset, we did not further perform subgroup analysis.

\section{Sensitivity analyses and publication bias}

For OS subgroup, Begg's test $(P=0.368)$ and Egger's test $(P=0.197)$ indicated the absence of publication bias (Figure 3). Sensitivity analyses by applying the trim-andfill method generated similar adjusted estimate (HR 0.98, $95 \%$ CI, 0.60 to 1.60 ) with the primary analyses. As there were only five studies included in the DFS/RFS/PFS subset, the publication bias was not examined.

\section{DISCUSSION}

\section{Principal findings of this study}

The results of this meta-analysis including 8 cohort studies enrolling 1622 patients showed a neutral prognostic effect of TL on CRC survival in terms of OS and DFS/RFS/PFS. Subgroup analyses found that long TL (versus short TL) was significantly associated with poor OS in studies conducted in Europe, using Southern blot to measure TL and patients' age more than 60 years. We found no significant associations between TL and patient DFS/RFS/PFS.

\section{Comparisons with previous studies}

Although the results reported within the current meta-analysis did not quite agree with previous ones which showed that TL was significantly associated with patient OS. Jia et al. repoted that short TL in peripheral blood leukocytes was significantly associated with poorer OS with fixed-effects model (HR 2.01, 95\% CI 1.46 to 2.77) by pooling data from four studies [21]. Zhang et al. also summarized the four studies and obtained similar result [20]. These two studies, however, have limited implications for this topic for the low statistical power 
with small sample size of included studies. Another recently published study by Adam et.al. [30] also found null association between TL and cancer outcomes. However, it is not just focused on CRC and with limited subgroup analyses.

\section{Strengths and limitations of the study}

There are some limitations to our study. First of all, despite the largest number of studies and patients included on the association between TL and CRC survival, most were small, single-center studies with a higher risk for biases. Secondly, the small number of included studies limited further subgroup analysis and had relatively lower statistical power of the relationship between TL and CRC outcomes. Moreover, DFS, RFS and PFS were combined as the same outcome which could lead to significant heterogeneity as these outcome measures were somewhat different. Moreover, covariants among the included studies are not completely consistent. Finally, several primary selected studies or abstracts were excluded due to the unavailability of original data, which might lead to publication bias for pooled estimates.

There are a number of important strengths for our study. Firstly, we used rigorous search strategies to systematically identify all relevant studies to examine the effect of TL on CRC outcomes. Secondly, significant inter-study heterogeneity was detected in terms of characteristics of observational studies, patient selection (study region, age, tumor stage, etc.), exposure factors (TL measurement methods, cutoffs for long and short TL), therapeutic schedules and outcome reported, though several prespecified subgroup analyses and sensitivity analysis were conducted to explore the sources of heterogeneity. Still several other sources of heterogeneity could not be determined. Additionally, some other factors, such as different study design (prospective versus retrospective), tumor $K R A S / B R A F / P I K 3 C A$ mutation status that affected the survival of CRC patients should also be attributed to some of the heterogeneity. Based on the results of subgroup analyses (Table 2), we noted that $\mathrm{I}^{2}$ was significantly reduced when analyses were stratified by research region, TL detection method and follow-up period, indicating that these three factors could be part of the sources of heterogeneity. Thirdly, we used a validated scale, NOS to assess the quality of the study evidence for every cohort as was suggested by Cochrane. Fourthly, a relatively large sample size including over 1500 patients made the quantitative analysis more reliable on the association between TL and CRC prognosis. Fifthly, we evaluated each citation by cross-checked means during the process of study screening, data abstraction and quality assessment to maximally minimize selection bias, making the systematic review more objectively.

In summary, current evidence did not provide solid indication that long TL is significantly associated with improved or poor survival for patients with CRC, although the real association remains to be further confirmed by

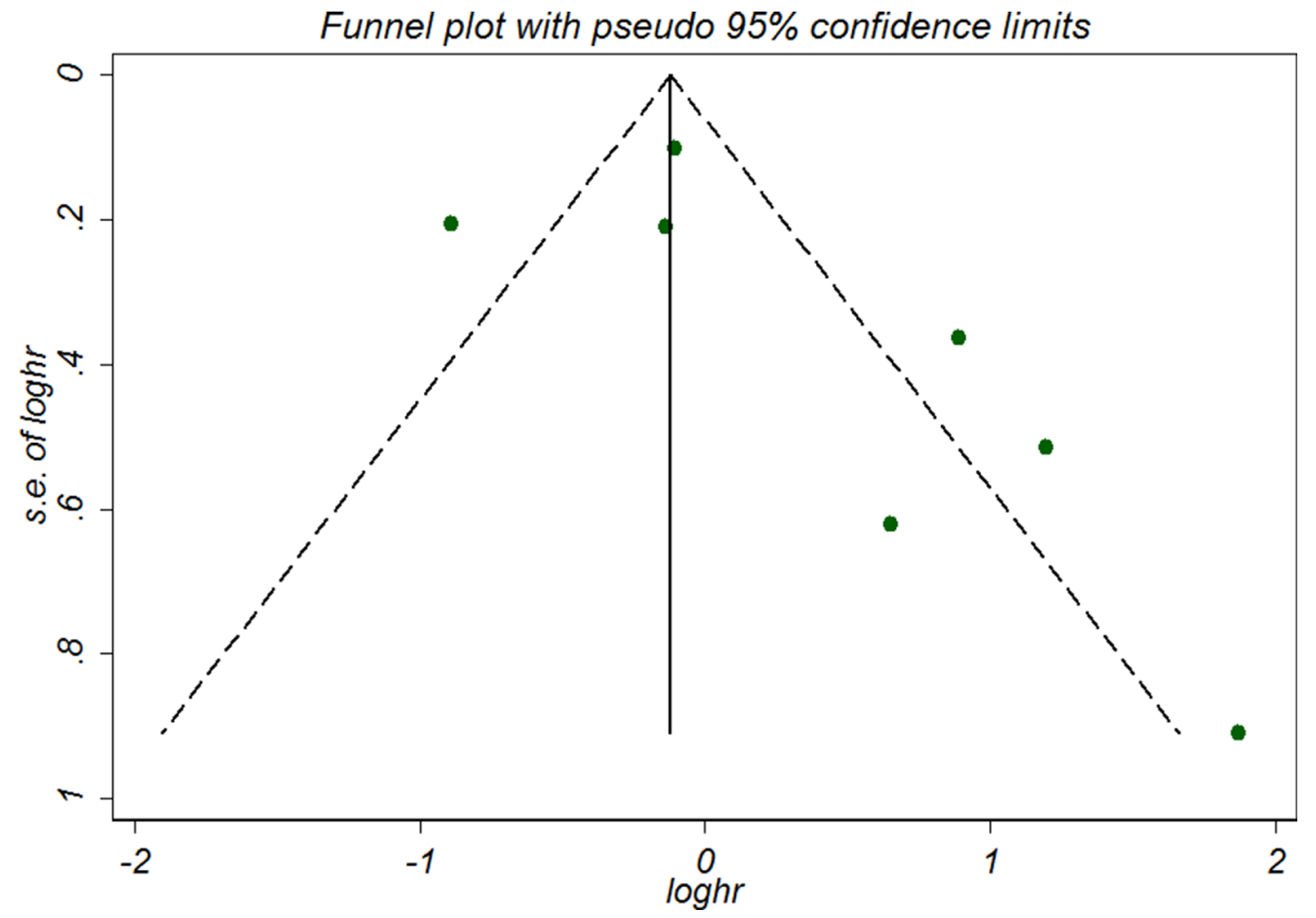

Figure 3: Funnel plot of included studies examining the association between telomere length and overall survival. 
the existing evidence. However, in some subgroups, it provides evidence that in specific population with standard TL detection method (Southern blot) or long-term followup ( $\geq 60$ months), long TL may serve as a prognostic biomarker for patients with CRC. Further large sample size prospective cohort studies are warranted to determine the true relationship for some of those specific patients.

\section{MATERIALS AND METHODS}

\section{Literature search}

We developed the search strategies based on the preferred reporting items for systematic reviews and meta-analysis (PRISMA) statement [31]. PubMed, Embase and the Cochrane Library Central Register of Controlled Trials databases from inception through April 2017 were systematically searched for studies investigating the associations between TL and CRC prognosis. Detailed search strategies of the above three databases were presented in Supplementary Table 1. In summary, the following searching terms or phrases with the combinations queries with Boolean logic were used: 'telomere' or 'telomeres' or 'telomeric', 'colorectal' or 'colonic' or 'rectal', 'cancer' or 'neoplas*' or 'carcinoma', 'mortality' or 'prognosis' or 'prognostic' or 'survival'. We limited the language of included studies only to English, as studies published in other languages were often difficult to interprete and not available for readers.

\section{Study selection}

Two investigators (W.W., L.Z. or N.Z.) evaluated the the titles or abstracts through the primary literature search independently. The final included articles were cross-checked for eligibility by a third investigator (Y.Z. or Y.T.) if necessary until agreement was reached. The inclusion criteria for study eligibility were set as follows: observational (prospective or retrospective) studies reported prognostic outcomes for blood sample or tumor tissue relative TL (long versus short) in CRC patients, and studies provided the definite survival data [risk estimates such as HRs/relative risks (RRs) with 95\% CIs obtained directly or estimated through other method [32]. For those overlapped prognostic data, the most recent and comprehensive one was selected for inclusion. Since the low quality of unpublished data and abstracts, we did not include these studies.

\section{Data extraction}

The study elements regarding the study design, patient characteristics, outcomes, exposure of each included study were extracted as follows: the first author and publication year, research country, study sample origin and sample size, mean/median patient age, tumor stage, treatment regimen, assay/detection method for TL, follow up period, outcome reported, adjustment factors and study quality.

\section{Quality assessment}

We applied NOS to assess the quality of each included study, which was calculated based on three major aspects of cohort studies including selection and comparability of study groups, ascertainment of the outcome of interest [33]. Two investigators scored the study quality independently (score range for cohort study 0-9), with a higher score representing better methodologic quality.

\section{Statistical analysis}

All the data were pooled using STATA software 12.0 (StataCorp LP, College Station, TX, USA). We abstracted study estimates (HRs or RRs with 95\% CIs) with full adjustments from the included studies and pooled using random-effects model [34] due to the proposed high inter-study heterogeneity. An estimated HR $>1$ implied a poor survival for the patient with longer TL (compared with shorter TL). Inter-study heterogeneity was assessed using $\mathrm{I}^{2}$ statistic and the Cochrane Q statistic, which was defined as an $\mathrm{I}^{2}>50 \%$ and $p$-value $<0.10$ indicating substantial heterogeneity, respectively [35]. If the potential heterogeneity existed, subgroup analyses were performed based on some of the baseline variables that the heterogeneity could attibute to.

Potential publication bias was evaluated by visual inspection of a funnel plot symmetry and by Egger's test or Begg's test [36, 37]. Duval's nonparametric trim-and-fill method [38] was also applied to adjust the pooled estimates for investigating the potential effect of publication bias.

\section{CONFLICTS OF INTEREST}

The authors disclose no potential conflicts of interest.

\section{REFERENCES}

1. $\mathrm{Xu} \mathrm{L,} \mathrm{Li} \mathrm{S,} \mathrm{Stohr} \mathrm{BA.} \mathrm{The} \mathrm{role} \mathrm{of} \mathrm{telomere} \mathrm{biology} \mathrm{in}$ cancer. Annu Rev Pathol. 2013; 8:49-78.

2. Blackburn EH. Switching and signaling at the telomere. Cell. 2001; 106:661-673.

3. Rampazzo E, Bertorelle R, Serra L, Terrin L, Candiotto C, Pucciarelli S, Del Bianco P, Nitti D, De Rossi A. Relationship between telomere shortening, genetic instability, and site of tumour origin in colorectal cancers. Br J Cancer. 2010; 102:1300.

4. Zhang R, Zhao J, Xu J, Liu F. Association of peripheral leukocyte telomere length and its variation with pancreatic cancer and colorectal cancer risk in Chinese population. 
Oncotarget. 2016; 7:38579-38585. http://doi.org/10.18632/ oncotarget.9536.

5. Seguí N, Guinó E, Pineda M, Navarro M, Bellido F, Lázaro C, Blanco I, Moreno V, Capellá G, Valle L. Longer telomeres are associated with cancer risk in MMR-proficient hereditary non-polyposis colorectal cancer. PloS One. 2014; 9.

7. Qin Q, Sun J, Yin J, Liu L, Chen J, Zhang Y, Li T, Shi Y, Wei S, Nie S. Telomere length in peripheral blood leukocytes is associated with risk of colorectal cancer in Chinese population. PloS one. 2014; 9:e88135.

8. Pellatt AJ, Wolff RK, Lundgreen A, Cawthon R, Slattery ML. Genetic and lifestyle influence on telomere length and subsequent risk of colon cancer in a case control study. Int J Mol Epidemiol Genet. 2012; 3:184-194.

9. Naing C, Aung K, Lai PK, Mak JW. Association between telomere length and the risk of colorectal cancer: a metaanalysis of observational studies. BMC cancer. 2017; 17:24.

10. Kapoor S. Leukocyte telomere length and colorectal cancer risk. Cancer Epidemiol Biomarkers Prev. 2013; 22:175.

11. Cui Y, Cai Q, Qu S, Chow WH, Wen W, Xiang YB, Wu J, Rothman N, Yang G, Shu XO, Gao YT, Zheng W. Association of leukocyte telomere length with colorectal cancer risk: nested case-control findings from the Shanghai Women's Health Study. Cancer Epidemiol Biomarkers Prev. 2012; 21:1807-1813.

12. Weischer M, Nordestgaard BG, Cawthon RM, Freiberg JJ, Tybjærg-Hansen A, Bojesen SE. Short telomere length, cancer survival, and cancer risk in 47102 individuals. J Natl Cancer Inst. 2013:djt016.

13. Sanchez-Espiridion B, Chen M, Chang JY, Lu C, Chang DW, Roth JA, Wu X, Gu J. Telomere length in peripheral blood leukocytes and lung cancer risk: a large case-control study in Caucasians. Cancer Res. 2014; 74:2476-2486.

14. Iles MM, Bishop DT, Taylor JC, Hayward NK, Brossard M, Cust AE, Dunning AM, Lee JE, Moses EK, Akslen LA. The effect on melanoma risk of genes previously associated with telomere length. J Natl Cancer Inst. 2014; 106.

15. Svenson U, Roos G. Telomere length as a biological marker in malignancy. Biochim Biophys Acta. 2009; 1792:317-323.

16. Svenson U, Nordfjäll K, Stegmayr B, Manjer J, Nilsson P, Tavelin B, Henriksson R, Lenner P, Roos G. Breast cancer survival is associated with telomere length in peripheral blood cells. Cancer Res. 2008; 68:3618-3623.

17. Heaphy CM, Yoon GS, Peskoe SB, Joshu CE, Lee TK, Giovannucci E, Mucci LA, Kenfield SA, Stampfer MJ, Hicks JL. Prostate cancer cell telomere length variability and stromal cell telomere length as prognostic markers for metastasis and death. Cancer Discov. 2013; 3:1130-1141.

18. Qu F, Li R, He X, Li Q, Xie S, Gong L, Ji G, Lu J, Bao G. Short telomere length in peripheral blood leukocyte predicts poor prognosis and indicates an immunosuppressive phenotype in gastric cancer patients. Mol Oncol. 2015; 9:727-739.

19. Kim ES, Ye Y, Vaporciyan AA, Xing J, Huang M, Gu J, Roth JA, Lippman SM, Wu X. Telomere length and recurrence risk after curative resection in patients with early-stage non-small-cell lung cancer: a prospective cohort study. J Thoracic Oncol. 2015; 10:302-308.

20. Zhang C, Chen X, Li L, Zhou Y, Wang C, Hou S. The association between telomere length and cancer prognosis: evidence from a meta-analysis. PloS one. 2015; 10:e0133174.

21. Jia H, Wang Z. Telomere Length as a Prognostic Factor for Overall Survival in Colorectal Cancer Patients. Cell Physiol Biochem. 2016; 38:122-128.

22. Valls C, Pinol C, Rene JM, Buenestado J, Vinas J. Telomere length is a prognostic factor for overall survival in colorectal cancer. Colorectal Dis. 2011; 13:1265-1272.

23. Svenson U, Oberg A, Stenling R, Palmqvist R, Roos G. Telomere length in peripheral leukocytes is associated with immune cell tumor infiltration and prognosis in colorectal cancer patients. Tumour Biol. 2016; 37:10877-10882.

24. Suraweera N, Mouradov D, Li S, Jorissen RN, Hampson D, Ghosh A, Sengupta N, Thaha M, Ahmed S, Kirwan M, Aleva F, Propper D, Feakins RM, et al. Relative telomere lengths in tumor and normal mucosa are related to disease progression and chromosome instability profiles in colorectal cancer. Oncotarget. 2016; 7:36474-36488. http:// doi.org/10.18632/oncotarget.9015.

25. Gertler R, Rosenberg R, Stricker D, Friederichs J, Hoos A, Werner M, Ulm K, Holzmann B, Nekarda H, Siewert JR. Telomere length and human telomerase reverse transcriptase expression as markers for progression and prognosis of colorectal carcinoma. J Clin Oncol. 2004; 22:1807-1814.

26. Garcia-Aranda C, de Juan C, Diaz-Lopez A, SanchezPernaute A, Torres AJ, Diaz-Rubio E, Balibrea JL, Benito M, Iniesta P. Correlations of telomere length, telomerase activity, and telomeric-repeat binding factor 1 expression in colorectal carcinoma. Cancer. 2006; 541-551.

27. Fernández-Marcelo T, Sánchez-Pernaute A, Pascua I, De Juan C, Head J, Torres-García A-J, Iniesta P. Clinical relevance of telomere status and telomerase activity in colorectal cancer. PloS one. 2016; 11:e0149626.

28. Chen Y, Qu F, He X, Bao G, Liu X, Wan S, Xing J. Short leukocyte telomere length predicts poor prognosis and indicates altered immune functions in colorectal cancer patients. Ann Oncol. 2014; 25:869-876.

29. Augustine TA, Baig M, Sood A, Budagov T, Atzmon G, Mariadason JM, Aparo S, Maitra R, Goel S. Telomere length is a novel predictive biomarker of sensitivity to antiEGFR therapy in metastatic colorectal cancer. Br J Cancer. $2015 ; 112: 313-318$.

30. Adam R, Díez-González L, Ocaña A, Šeruga B, Amir E, Templeton A. Prognostic role of telomere length in malignancies: A meta-analysis and meta-regression. Exp Mol Pathol. 2017; 102:455.

31. Moher D, Liberati A, Tetzlaff J, Altman DG, Group P. Preferred reporting items for systematic reviews and meta-analyses: the PRISMA statement. PLoS med. 2009; 6:e1000097. 
32. Parmar MK, Torri V, Stewart L. Extracting summary statistics to perform meta-analyses of the published literature for survival endpoints. Stat Med. 1998; 17:2815-2834.

33. Stang A. Critical evaluation of the Newcastle-Ottawa scale for the assessment of the quality of nonrandomized studies in meta-analyses. Eur J Epidemiol. 2010; 25:603-605.

34. Van Houwelingen HC, Arends LR, Stijnen T. Advanced methods in meta-analysis: multivariate approach and metaregression. Stat Med. 2002; 21:589-624.

35. Higgins J, Thompson SG. Quantifying heterogeneity in a meta-analysis. Stat Med. 2002; 21:1539-1558.
36. Begg CB, Mazumdar M. Operating characteristics of a rank correlation test for publication bias. Biometrics. 1994: 1088-1101.

37. Egger M, Smith GD, Schneider M, Minder C. Bias in metaanalysis detected by a simple, graphical test. BMJ. 1997; 315:629-634.

38. Duval S, Tweedie R. Trim and fill: a simple funnel-plotbased method of testing and adjusting for publication bias in meta-analysis. Biometrics. 2000; 56:455-463. 